\title{
PHD THESIS SUMMARY: \\ The Viennese students of civilization: humility, culture and economics in interwar Vienna and beyond
}

\author{
ERWIN DEKKER \\ PhD in (Cultural) Economics, January 2014 \\ Erasmus University Rotterdam
}

This dissertation argues that the group of interwar scholars who are usually known under the banner Austrian Economists-including Carl Menger, Friedrich von Wieser, Joseph Schumpeter, Ludwig von Mises, and Friedrich Hayek - are better understood as the 'Viennese students of civilization'. Contrary to many economists-both then and now-the Viennese students of civilization understood the economy neither as a self-regulating natural order nor as a system which could be planned, but rather as a cultural process: just like language and law, markets emerge and develop from human interaction. As a cultural process the market economy has both important cultural effects and is sustained by what we could call a market culture.

In this dissertation the cultural effects of the market are explored especially as they relate to restraint. For the Viennese scholars restraint was the central element of civilization, but I also show its centrality for a wider group of Central European scholars, including Sigmund Freud, Bronislaw Malinowski, and Norbert Elias. The Viennese students of civilization, especially Wieser, Mises, and Hayek, believed that they lived in a particularly unrestrained age. This had fuelled opposition to market and other cultural institutions which were not rationally constructed. The acceptance and cultivation of the market economy came at a cost they called the 'strain of civilization'. That cost is primarily the restraint of our innate instincts. Civilization requires the acceptance of certain norms-of individual responsibility, the acceptance of differences and inequality. This price however was no longer accepted by the social scientists of their time, who preached unrestrained rationalism. And it was no longer accepted by the mass political movements, such as socialism and fascism, which promised to relieve the people of this strain. 
During the interwar period the Viennese students felt that their civilization was in acute danger. They analyzed this revolt, and their own role in the process. Initially their response was largely passive and accepting, an attitude characteristic of a Viennese cultural trait known as 'therapeutic nihilism'. The social scientist, or rather student, could study the cultural tectonics of their society, but they are outside his or her control. Yet the Viennese students also criticized many of their contemporaries for being under the illusion that they could predict the course of society, and ultimately of history. This outsider-perspective, however, was seriously challenged during the course of the interwar period, especially during the rise of fascism.

The Viennese intellectuals increasingly realized that they bore a responsibility toward their culture, and that they might even possibly have some influence over its fate. This put them in an awkward position. Their work became more political and idealistic, features which they had criticized in the work of others. Hayek's The road to serfdom (1944) and Karl Popper's The open society and its enemies (1945) are outcomes of this tension between the recognition of the limited power of the scholar and the desire to defend a civilization under pressure. In their work Hayek and Popper apologized to their colleagues for the political nature of their books, but they felt obliged to write them nonetheless as their 'war effort'. Ultimately, although reluctantly, they attempted to draw up ideals and plans for the future. They regained some hope, in part because they were now no longer writing for a Continental but for an Anglo-Saxon audience. It is also in this sense that Hayek and Popper were engaged in a new kind of liberalism, one that intended to be resistant to mass political movements and the desire to throw off cultural restraints.

This dissertation draws heavily on the cultural histories of finde-siècle and interwar Vienna. It shows similarities in the problems faced by artists, novelists, scientists and politicians in Vienna. Such similarities were sometimes incidental, but they also arose out of the interactions within and between the various Viennese circles (Kreise). In these partly overlapping circles, broad intellectual conversations were stimulated and this greatly contributed to the creativity of the contributions emerging out of Vienna, especially during the interwar period. The prominence of these circles partly accounts for the fact that the Viennese students of civilization crossed many interdisciplinary 
boundaries, and that their intellectual concerns were driven as much by social and political issues as by scientific ones.

Erwin Dekker did his doctoral research at the Erasmus School of History, Culture and Communication (ESHCC) at Erasmus University Rotterdam (Netherlands) under the supervision of Prof. Arjo Klamer. He is currently assistant professor in cultural economics at the ESHCC where he is working on a research project about the valuation of cultural goods. Previously, he lectured at the European Studies department at the University of Amsterdam, where he specialized in political economy.

Contact e-mail: <e.dekker@eshcc.eur.nl> 